\title{
A Study of the Interaction between Cucurbit[7]uril and Alkyl Substituted 4-Pyrrolidinopyridinium Salts
}

\author{
Weitao Xu ${ }^{1}$, Xinyi Zhu ${ }^{1}$, Bing Bian ${ }^{2}$, Xin Xiao ${ }^{1, *}$, Zhu Tao $^{1}$ and Carl Redshaw ${ }^{3, *}$ (]) \\ 1 Key Laboratory of Macrocyclic and Supramolecular Chemistry of Guizhou Province, Guizhou University, \\ Guiyang 550025, China; xxz_xwt@163.com (W.X.); zxy18355451912@163.com (X.Z.); gzutao@263.net (Z.T.) \\ 2 College of Chemistry and Environmental Engineering, Shandong University of Science and Technology, \\ Qingdao 266590, China; bianbing@sdust.edu.cn \\ 3 Department of Chemistry \& Biochemistry, University of Hull, Hull HU6 7RX, UK \\ * Correspondence: gyhxxiaoxin@163.com (X.X.); c.redshaw@hull.ac.uk (C.R.); \\ Tel.: +86-155-1908-9928 (X.X.); +44-148-246-5219 (C.R.)
}

Received: 28 February 2020; Accepted: 8 April 2020; Published: 14 April 2020

\begin{abstract}
The interaction between cucurbit[7]uril (Q[7]) and a series of 4-pyrrolidinopyridinium salts bearing aliphatic substituents at the pyridinium nitrogen, namely $4-\left(\mathrm{C}_{4} \mathrm{H}_{8} \mathrm{~N}\right) \mathrm{C}_{5} \mathrm{H}_{5} \mathrm{NRBr}$, where $\mathrm{R}=\mathrm{H}(\mathrm{C} 0)$, Et (C2), n-butyl (C4), n-hexyl (C6), has been studied in aqueous solution by ${ }^{1} \mathrm{H}$ NMR spectroscopy, electronic absorption spectroscopy, and mass spectrometry.
\end{abstract}

Keywords: host-guest interaction; cucurbit[7]uril; 4-pyrrolidinopyridinium

\section{Introduction}

The behavior of a host toward a guest is typically controlled by non-covalent interactions, and this can impact greatly on the properties exhibited by the guest [1-3]. Given this, supramolecular approaches have been used extensively to construct functional materials, and these have seen applications in a number of areas, for example, in molecular electronics, drug-delivery, optical sensors, and for molecular machines [4-8]. In recent years, new host-guest systems have been reported that employ hosts comprising calix $[n]$ arenes, crown ethers, pillararenes, cyclodextrins, or cucurbit $[n]$ urils [9-14]. Indeed, during the last two decades, the host-guest chemistry of the cucurbit $[n]$ uril $(n=5-8,10)$ family has started to flourish $[15,16]$, and this is now impacting on exciting new applications in the fields of materials, biomedicine, sensors, and catalysis [17-20].

In 1983, Mock et al., were the first to study the complexation of alkylammonium and alkyldiammonium ions with Q[6] in aqueous formic acid and to determine their binding affinities [21]. However, there have been few applications of Q[6] in host-guest chemistry due to its small cavity diameter and poor aqueous solubility. In contrast, Q[7] not only has a cavity size amenable to the encapsulation of sizable guest molecules, but also has a much greater aqueous solubility relative to other members of the $\mathrm{Q}[n]$ family. For example, $\mathrm{Q}$ [7] exhibits a water solubility of $30 \mathrm{mM}$ compared to $0.01 \mathrm{mM}$ for $\mathrm{Q}[8]$ or $\mathrm{Q}[10]$ [18]. This greater solubility, coupled with the larger cavity volume, has resulted in a variety of specific applications of Q[7] systems in aqueous solution [22].

In our previous research, for a series of guests with the same 'central motif', but with different alkyl chain substituents, we found that the length of the alkyl chain determined the mode of interaction with the $\mathrm{Q}[n][23,24]$. Therefore, for the same type of $\mathrm{Q}[n]$, we can establish different host-guest interaction modes simply by adjusting the length of the alkyl chain, thereby obtaining host-guest materials with different properties. In the case of Q[8], for a series of 4-pyrrolidinopyridinium guests bearing aliphatic substituents at the pyridinium nitrogen, studies in aqueous solution revealed that the alkyl chain at the pyridinium nitrogen can either reside in the Q[8] cavity along with the rest of 
the guest (as observed for $\mathrm{R}=n$-hexyl, $n$-octyl, $n$-dodecyl), can be found outside the $\mathrm{Q}[8]$ with the rest of the guest inside (as seen for $\mathrm{R}=\mathrm{Et}$ ), or that the two species can exist in equilibrium for which either the chain or the rest of the guest is encapsulated by the Q[8]. In the solid-state, the structures are somewhat different (in the case of Q[8]@g2, two Q[8] molecules are filled with a centro-symmetric pair of guest molecules) with the cyclic amine encapsulated, and the molecule enters at a rather shallow angle. Interestingly for Q[8]@g3, the two Q[8] molecules behave in different ways. In particular, for one Q[8], the cyclic amine of the guest enters the ring at a rather shallow angle, but for the other Q[8], it is the alkyl chain of the guest that enters the ring with the four carbon atoms of the alkyl chain almost perpendicular to the cavity opening and almost completely encapsulated by the Q[8]). It is well known that the portal diameter and cavity volume of Q[7] $\left(7.3 \AA, 279 \AA^{3}\right)$ are less than $Q[8](8.8 \AA$, $479 \AA^{3}$ ) [6,25]. Herein, we examined the interaction of the same family of guests with Q[7] (see Scheme 1) and compared the behavior with that observed for Q[8]. Given that 4-pyrrolidinopyridines have seen widespread use as catalysts in acyl transfer reactions, [26-28] information about their bonding actions can provide insight into their behavior and may inform such catalytic research.

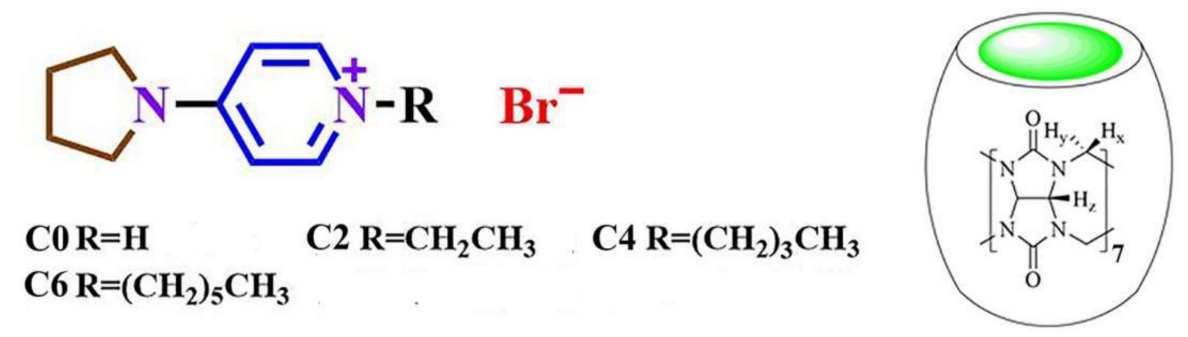

Scheme 1. The guests and Q[7] used in this study.

\section{Materials and Methods}

To analyze the host-guest complexation between Q[7] and C0/C2/C4/C6, 2.0-2.5 $\times 10^{-3} \mathrm{mmol}$ solutions of $\mathrm{Q}[7]$ in $0.5-0.7 \mathrm{~mL} \mathrm{D}_{2} \mathrm{O}$ with $\mathrm{Q}[7]: \mathrm{C} 0 / \mathrm{C} 2 / \mathrm{C} 4 / \mathrm{C} 6$ ratios ranging between 0 and 2 were prepared. All ${ }^{1} \mathrm{H}$ NMR spectra including those for the titration experiments were recorded at $298.15 \mathrm{~K}$ on a JEOL JNM-ECZ400S $400 \mathrm{MHz}$ NMR spectrometer (JEOL, Akishima, Japan) in $\mathrm{D}_{2} \mathrm{O}$. $\mathrm{D}_{2} \mathrm{O}$ was used as a field-frequency lock, and the observed chemical shifts were reported in parts per million (ppm).

All UV-Visible spectra were recorded from samples in $1 \mathrm{~cm}$ quartz cells on an Agilent 8453 spectrophotometer, equipped with a thermostat bath (Hewlett Packard, CA, USA). The host and guests were dissolved in distilled water. UV-Visible spectra were obtained at $25{ }^{\circ} \mathrm{C}$ at a concentration of $2.00 \times 10^{-5} \mathrm{~mol} \cdot \mathrm{L}^{-1} \mathrm{Ci}(\mathrm{i}=0,2,4,6)$ and different $\mathrm{Q}[7]$ concentrations for the Q[7]@Ci $(\mathrm{i}=0,2,4,6)$ system. The MALDI-TOF mass spectra were recorded on a Bruker BIFLEX III mass spectrometer with $\alpha$-cyano-4-hydrox-ycinnamic acid as the matrix.

\section{Results and Discussion}

\subsection{NMR Spectroscopy}

The binding interactions between each of the pyrrolidinopyridinium guests and Q[7] can be conveniently monitored using ${ }^{1} \mathrm{H}$ NMR spectroscopic data recorded in neutral $\mathrm{D}_{2} \mathrm{O}$ solution.

In the case of $\mathrm{C} 0$, Figure 1 shows the changes observed in the ${ }^{1} \mathrm{H}$ NMR spectrum of $\mathrm{C} 0$ as progressively larger amounts of Q[7] were added to the $\mathrm{D}_{2} \mathrm{O}$ solution at $25^{\circ} \mathrm{C}$. Spectrum A was obtained in the absence of Q[7], B with Q[7] at 0.326 (B), C with 0.487 equivalents with progressive increasing amounts up to spectrum I with 1.939 equivalents of $\mathrm{Q}[7]$ in $\mathrm{D}_{2} \mathrm{O}$ (D) at $20^{\circ} \mathrm{C}$. The peaks associated with protons a-d all experienced upfield shifts as increasing amounts of Q[7] was added (for specific shift changes, see Table A1, ESI). This is consistent with the complete encapsulation of C0 as depicted in the image shown top right, Figure 1. For the COSY NMR spectrum of this system with 1.939 equivalents of C0, see Figure A1, ESI. 


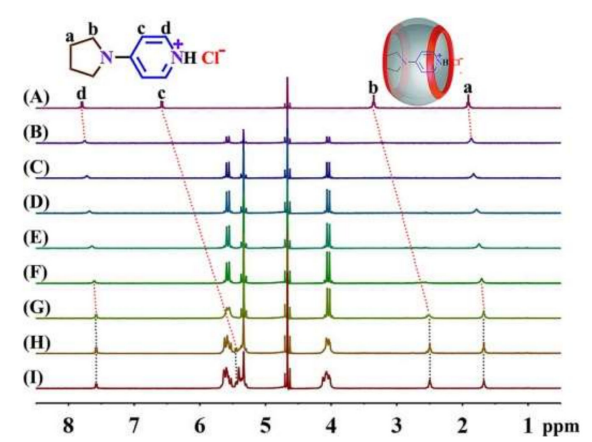

Figure 1. Interaction of $\mathrm{C} 0$ and $\mathrm{Q}[7]\left(25^{\circ} \mathrm{C}\right):{ }^{1} \mathrm{H}$ NMR spectra $\left(400 \mathrm{MHz}, \mathrm{D}_{2} \mathrm{O}\right)$ of $\mathrm{C} 0(\mathrm{ca} .0 .5 \mathrm{mM})$ in the absence (A), 0.191 equiv. (B), 0.326 equiv. Q[7] (C), 0.487 equiv. (D), 0.663 equiv. Q[7] (E), 0.838 equiv. (F), 0.930 equiv. (G), 1.570 equiv. (H), and 1.939 equiv. of Q[7] (I).

In the case of C2, similar analysis (Figure 2) of the system involving Q[7] and C2 revealed that the peaks associated with the ethyl chain, particularly the methyl group (f), did not undergo any significant changes. However, the remaining peaks associated with the protons of the pyridine and pyrrole rings did undergo an upfield shift (for specific shift changes, see Table A2). This situation, whereby the pyridine and pyrrole rings are accommodated within the cavity of Q[7] is reminiscent of that observed for Q[8] [23] and the same guest. There may be slight differences with regard to how much the alkyl chain protrudes out of the cavity for Q[7] versus $\mathrm{Q}[8]$, but the ${ }^{1} \mathrm{H}$ NMR spectra suggest the difference is small (the change of chemical shifts between these two systems is not obvious).

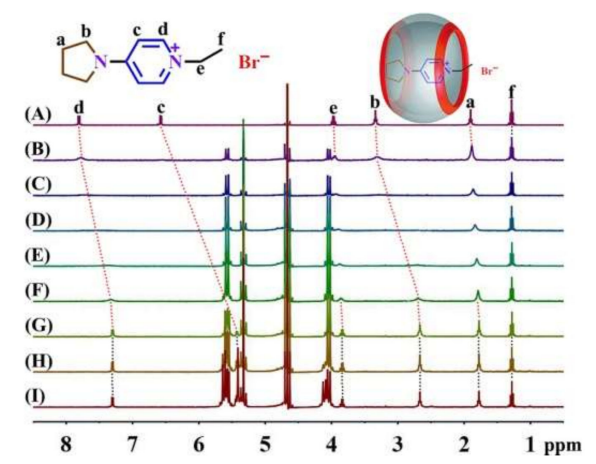

Figure 2. Interaction of $\mathrm{C} 2$ and $\mathrm{Q}[7]\left(25{ }^{\circ} \mathrm{C}\right):{ }^{1} \mathrm{H}$ NMR spectra $\left(400 \mathrm{MHz}, \mathrm{D}_{2} \mathrm{O}\right)$ of $\mathrm{C} 2(\mathrm{ca} .0 .5 \mathrm{mM})$ in the absence (A), 0.133 equiv. (B), 0.273 equiv. Q[7] (C), 0.453 equiv. (D), 0.595 equiv. Q[7] (E), 0.755 equiv. (F), 0.926 equiv. (G), 1.415 equiv. (H), and 1.733 equiv. of Q[7] (I).

In the case of $\mathrm{C} 4$, the ${ }^{1} \mathrm{H}$ NMR titration spectra of $\mathrm{C} 4 / \mathrm{Q}[7]$ in $\mathrm{D}_{2} \mathrm{O}$ are presented in Figure 3. There was a clear upfield shift of the signals of all protons in the pyridine ring, whilst the pyrrole ring and alkyl chain protons were also shifted upfield, though to a lesser degree (for specific shift changes, see Table A3, ESI). This indicates that the pyridine ring, pyrrole ring, and the alkyl chain are all accommodated within the cavity of Q[7], and that the Q[7] is capable of shuttling on the guest C4 in a state of dynamic equilibrium. For the COSY NMR spectrum of this system with 1.939 equivalents of C4, see Figure A2, ESI. This shuttling situation is reminiscent of that observed for $\mathrm{Q}[8]$ and the same guest. 


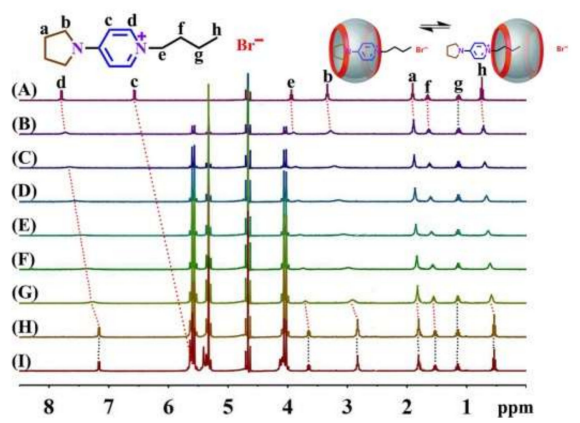

Figure 3. Interaction of $\mathrm{C} 4$ and $\mathrm{Q}[7]\left(25^{\circ} \mathrm{C}\right):{ }^{1} \mathrm{H}$ NMR spectra $\left(400 \mathrm{MHz}, \mathrm{D}_{2} \mathrm{O}\right)$ of $\mathrm{C} 4(\mathrm{ca} .0 .5 \mathrm{mM})$ in the absence (A), 0.116 equiv. (B), 0.173 equiv. Q[7] (C), 0.331 equiv. (D), 0.474 equiv. Q[7] (E), 0.641 equiv. (F), 0.750 equiv. (G), 1.164 equiv. (H), and 1.653 equiv. of $\mathrm{Q}[7]$ (I).

In the case of $\mathrm{C} 6$, Figure 4 depicts the ${ }^{1} \mathrm{H} N M R$ titration spectra of the $\mathrm{C} 6 / \mathrm{Q}[7]$ in $\mathrm{D}_{2} \mathrm{O}$. All the protons of the guest experienced upfield shifts to varying degrees (for specific shift changes, see Table A4, ESI). There was little change on increasing the Q[7] concentration beyond the addition of 0.997 equivalents. The situation is consistent with the pyridine ring, pyrrole ring, and the alkyl chain all being accommodated within the cavity of Q[7], and with the Q[7] shuttling on the guest C6 in a state of dynamic equilibrium. This contrasts with the situation observed for the same guest and Q[8], in which the pyridine ring, the alkyl chain, and the $\mathrm{N}$ part of the pyrrole were accommodated within the cavity of Q[8], and the another part of pyrrole was at its portal; the alkyl chain was buried in the cavity of $\mathrm{Q}[8]$ in a twisted form. The reason for the different inclusion modes involving C6 is likely to be related to the smaller cavity size of Q7 versus Q8, which prevents the alkyl chain from bending in the cavity of Q7.

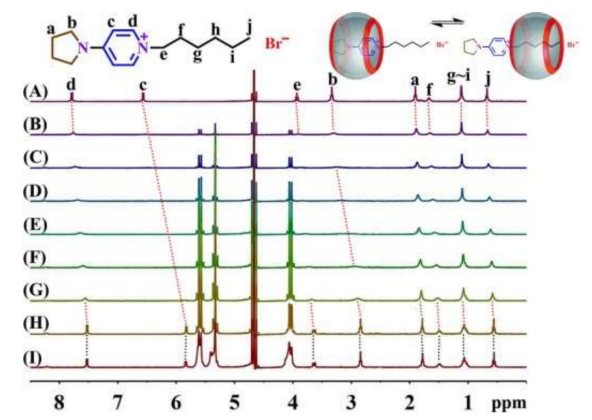

Figure 4. Interaction of $\mathrm{C} 6$ and Q[7] $\left(25^{\circ} \mathrm{C}\right):{ }^{1} \mathrm{H}$ NMR spectra $\left(400 \mathrm{MHz}, \mathrm{D}_{2} \mathrm{O}\right)$ of $\mathrm{C} 6(\mathrm{ca} .0 .5 \mathrm{mM})$ in the absence (A), 0.110 equiv. (B), 0.223 equiv. Q[7] (C), 0.363 equiv. (D), 0.461 equiv. Q[7] (E), 0.646 equiv. (F), 0.739 equiv. (G), 0.997 equiv. (H), and 1.494 equiv. of Q[7] (I).

\subsection{Ultraviolet (UV) Spectroscopy}

To further understand the binding of these 4-pyrrolidinopyridinium salts to Q[7], we also investigated the systems by UV-Vis spectroscopy. The UV spectra were obtained using aqueous solutions containing a fixed concentration of guests $\mathrm{C} 0-\mathrm{C} 6$ and variable concentrations of Q[7] (Figures 5 and A3, Figures A4 and A5). All systems of action showed similar phenomena, and here, only the interactions between Q[7] and guest $\mathrm{C} 2$ are described as an example. On gradually increasing the $\mathrm{Q}[7]$ concentration in the $\mathrm{C} 2$ solution, the absorption band of the guest exhibited a progressively higher absorbance due to the formation of the host-guest complex Q[7]@C2. The absorbance vs. ratio of $n(Q[7]) / n(C 2)$ data can be fitted to a 1:1 binding model. The pyrrolidinopyridinium part of the guest was encapsulated into the cavity of the Q[7] host, whilst the alkyl moiety remained outside. This generated a 1:1 host-guest inclusion complex. The encapsulation by Q[7] of this guest is presumably due to the favorable ion-dipole interactions between the positively charged guest and the portal oxygen atoms of Q[7] in addition to hydrophobic effects. Moreover, the association constant 
$(\mathrm{K})$ is calculated from the UV-vis spectroscopy data according to the modified Benesi-Hildebrand (B-H) equation. For these systems, the binding constants have determined as $\mathrm{Ka}(\mathrm{Q}[7] @ \mathrm{C} 0)=8.0 \times 10^{6}$, $\mathrm{Ka}(\mathrm{Q}[7] @ \mathrm{C} 2)=5.7 \times 10^{9}, \mathrm{Ka}(\mathrm{Q}[7] @ \mathrm{C} 4)=3.6 \times 10^{7}$ and $\mathrm{Ka}(\mathrm{Q}[7] @ \mathrm{C} 6)=2.5 \times 10^{9}$.

(A)

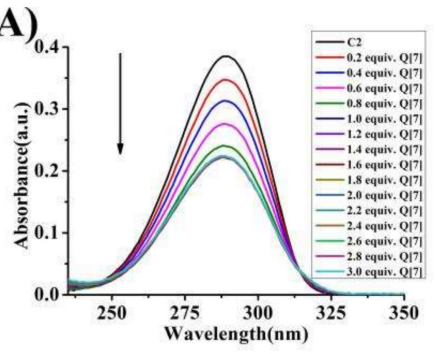

(B)

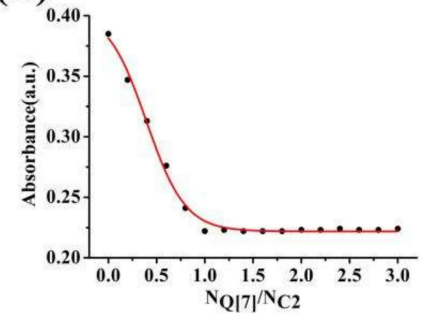

(C)

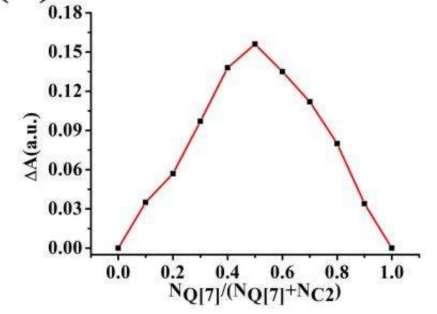

Figure 5. (Color online) (A) Electronic absorption of $\mathrm{C} 2\left(2 \times 10^{-5} \mathrm{~mol} \mathrm{~L}^{-1}\right)$ upon addition of increasing amounts $\left(0,0.2,0.4 \cdots \cdots \cdot 2.6,2.8,3.0\right.$ equiv.) of $\mathrm{Q}[7] ;$ (B) the concentrations and absorbance vs. $\mathrm{N}_{\mathrm{Q}[7]} / \mathrm{N}_{\mathrm{C} 2}$ plots; (C) the corresponding $\Delta \mathrm{A}-\mathrm{N}_{\mathrm{Q}[7]} /\left(\mathrm{N}_{\mathrm{Q}[7]}+\mathrm{N}_{\mathrm{C} 2}\right)$ curves.

\subsection{Mass Spectrometry}

The nature of the inclusion complexes between Q[7] and the 4-pyrrolidinopyridinium guests was also established by the use of MALTI-TOF mass spectra, as shown in Figure 6. Intense signals were found at 1311.080, 1339.624, 1367.817, 1395.699, 1423.788, and 1479.762, which corresponded to $\left[(\mathrm{Q}[7] @ \mathrm{C} 0)-\mathrm{Cl}^{-}\right]^{+}$(calculated as 1312.196), [(Q[7]@C2)-Br- $]^{+}$(calculated as 1340.250), [(Q[7]@C4)-Br- ${ }^{+}$ (calculated as 1368.304) and $\left[(\mathrm{Q}[7] @ \mathrm{C} 6)-\mathrm{Br}^{-}\right]^{+}$(calculated as 1396.358), respectively, thereby providing support for the formation of 1:1 host-guest inclusion complexes.
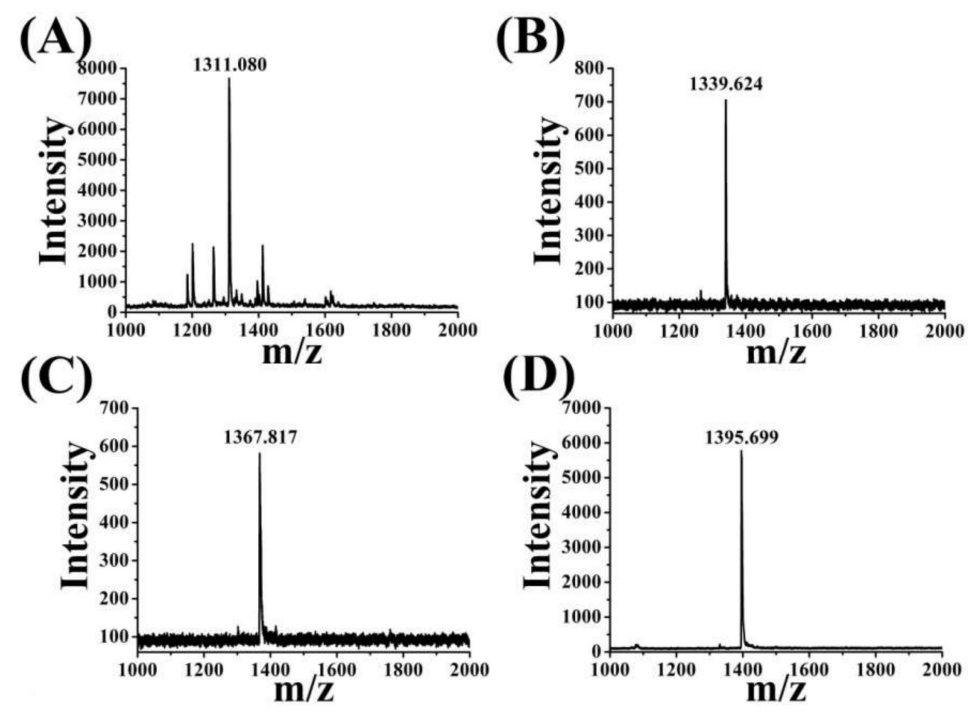

Figure 6. MALDI-TOF mass spectrometry of Q[7]@C0 (A), Q[7]@C2 (B), Q[7]@C4 (C), and Q[7]@C6 (D).

\section{Conclusions}

In summary, we investigated the binding interactions of $Q[7]$ with a series of 4-pyrrolidinopyridinium guests (namely C0, C2, C4, C6) bearing aliphatic substituents at the pyridinium nitrogen by using ${ }^{1} \mathrm{H}$ NMR and UV spectroscopy and mass spectrometry. The results herein revealed that for $\mathrm{C} 0$, the entire $\mathrm{C} 0$ molecule is encapsulated in the cavity of Q7. For $\mathrm{C} 2$, the pyridine and pyrrole rings are accommodated within the cavity of Q[7] and this is reminiscent of the situation observed for Q[8] and the same guest, but the difference between $\mathrm{Q}[7]$ and $\mathrm{Q}[8]$ is whether the alkyl chain is completely at its portal. For C4, this shuttling situation is reminiscent of that observed for $\mathrm{Q}[8]$ and the same guest. For $\mathrm{C} 6$, the shuttling situation herein is in contrast with that observed previously for Q[8], where the alkyl chain was twisted and buried in the Q[8] cavity; only part of 
pyrrole ring protruded from the portal. Based on this work and the previous results for the same guests with Q[8], we found that, for larger guests in particular, the size of the cavity of the cucuribit $[n]$ uril dictates the interaction between the cucuribit[ $n]$ uril and guest. This is illustrated herein for $\mathrm{C} 6$, where there is insufficient space in the Q[7] system to allow for the bending of the alkyl chain previously observed for the $\mathrm{Q}[8]$ system. Among the $\mathrm{Q}[n]$-based rotaxane/pseudorotaxane systems, most of the axle molecules have been built from ammonium, pyridinium ions, and viologen derivatives [17-20]. In comparison with previously reported cucurbit[7]uril-based host-guest systems (such as pyridinium ions, viologen derivatives), the interaction mode is similar $[6,25]$. This provides more insight into the possible applications of systems such as switchable mechanically pseudorotaxane molecules, for instance, in the area of supramolecular materials science.

Author Contributions: The main work of W.X. and X.Z. was to complete the experiment; B.B. participated in the optimization of the MS experiment; Manuscript writing by X.X., Z.T., and C.R. All authors have read and agree to the published version of the manuscript.

Funding: The Natural Science Foundation of China (21861011), the Major Program for Creative Research Groups of Guizhou Provincial Education Department (2017-028), the Innovation Program for High-level Talents of Guizhou Province (No. 2016-5657), and the Science and Technology Fund of Guizhou Province (No. 2018-5781) are gratefully acknowledged for their financial support. CR thanks the EPSRC (Engineering and Physical Sciences Research Council) for a travel grant (EP/L012804/1).

Conflicts of Interest: The authors declare no conflicts of interest.

\section{Appendix A}

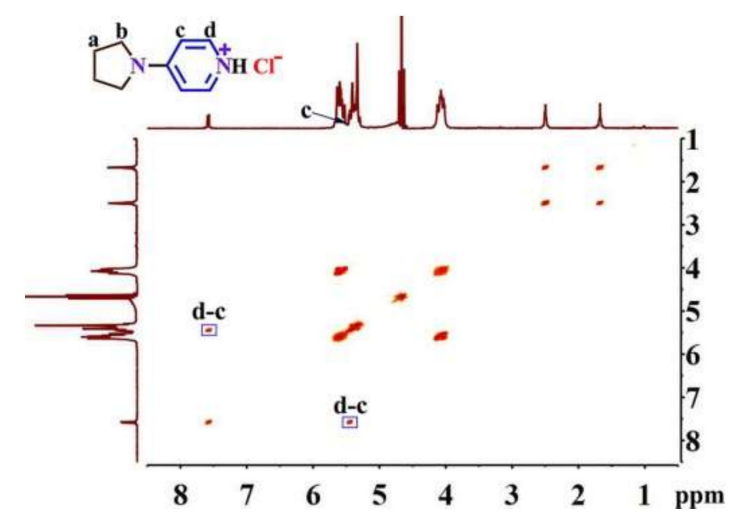

Figure A1. The COSY spectrum of C0 with 1.939 equivalent of $\mathrm{Q}[7]$ in $\mathrm{D}_{2} \mathrm{O}(400 \mathrm{MHz})$.

Table A1. Data from the ${ }^{1} \mathrm{H}$ NMR spectra for the interaction of $\mathrm{C} 0$ and different proportions of Q[7].

\begin{tabular}{ccccc}
\hline & Hd & Hc & Hb & Ha \\
\hline $\mathrm{C} 0$ & 7.80 & 6.58 & 3.35 & 1.91 \\
\hline $0.191 \mathrm{Q}[7]$ & 7.75 & $\backslash$ & $\backslash$ & 1.86 \\
\hline $0.326 \mathrm{Q}[7]$ & 7.72 & $\backslash$ & $\backslash$ & 1.83 \\
\hline $0.487 \mathrm{Q}[7]$ & 7.68 & $\backslash$ & $\backslash$ & 1.79 \\
\hline $0.663 \mathrm{Q}[7]$ & 7.64 & $\backslash$ & $\backslash$ & 1.75 \\
\hline $0.838 \mathrm{Q}[7]$ & 7.61 & $\backslash$ & 2.60 & 1.70 \\
\hline $0.930 \mathrm{Q}[7]$ & 7.58 & $\backslash$ & 2.51 & 1.67 \\
\hline $1.570 \mathrm{Q}[7]$ & 7.58 & 5.45 & 2.50 & 1.67 \\
\hline $1.939 \mathrm{Q}[7]$ & 7.58 & 5.45 & 2.50 & 1.67 \\
\hline
\end{tabular}


Table A2. Data from the ${ }^{1} \mathrm{H}$ NMR spectra for the interaction of C2 and different proportions of Q[7].

\begin{tabular}{ccccccc}
\hline & Hd & Hc & He & Hb & Ha & Hf \\
\hline $\mathrm{C} 2$ & 7.81 & 6.57 & 3.97 & 3.34 & 1.90 & 1.28 \\
\hline $0.133 \mathrm{Q}[7]$ & 7.78 & $\backslash$ & 3.95 & 3.31 & 1.88 & 1.28 \\
\hline $0.273 \mathrm{Q}[7]$ & $\backslash$ & $\backslash$ & 3.93 & $\backslash$ & 1.86 & 1.28 \\
\hline $0.453 \mathrm{Q}[7]$ & $\backslash$ & $\backslash$ & 3.90 & $\backslash$ & 1.83 & 1.28 \\
\hline $0.595 \mathrm{Q}[7]$ & $\backslash$ & $\backslash$ & 3.87 & $\backslash$ & 1.81 & 1.28 \\
\hline $0.755 \mathrm{Q}[7]$ & 7.32 & $\backslash$ & 3.85 & 2.69 & 1.79 & 1.28 \\
\hline $0.926 \mathrm{Q}[7]$ & 7.30 & 5.43 & 3.84 & 2.66 & 1.77 & 1.28 \\
\hline $1.415 \mathrm{Q}[7]$ & 7.30 & $\backslash$ & 3.84 & 2.66 & 1.77 & 1.28 \\
\hline $1.733 \mathrm{Q}[7]$ & 7.30 & $\backslash$ & 3.84 & 2.66 & 1.77 & 1.28 \\
\hline
\end{tabular}

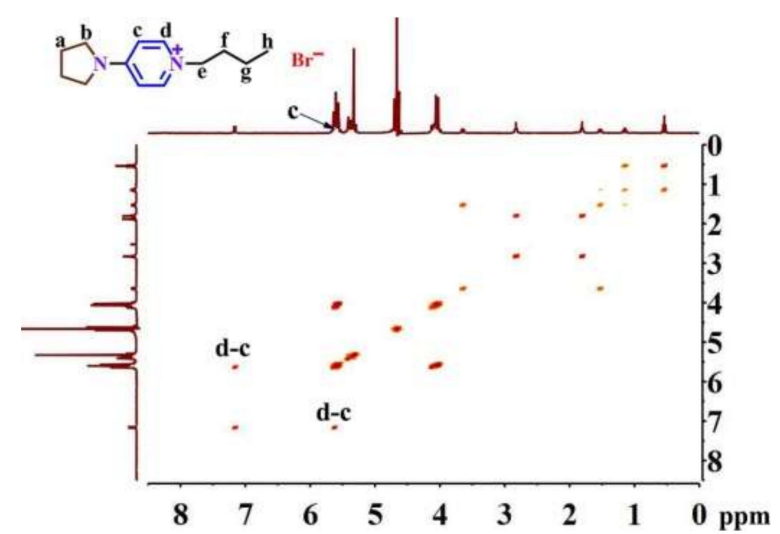

Figure A2. The COSY spectrum of C4 with 1.653 equivalent of $\mathrm{Q}[7]$ in $\mathrm{D}_{2} \mathrm{O}(400 \mathrm{MHz})$.

Table A3. Data from the ${ }^{1} \mathrm{H}$ NMR spectra for the interaction of C4 and different proportions of Q[7].

\begin{tabular}{ccccccccc}
\hline & Hd & Hc & He & Hb & Ha & Hf & Hg & Hh \\
\hline $\mathrm{C} 4$ & 7.79 & 6.57 & 3.94 & 3.33 & 1.90 & 1.65 & 1.13 & 0.75 \\
\hline $0.116 \mathrm{Q}[7]$ & 7.73 & $\backslash$ & 3.90 & 3.28 & 1.89 & 1.63 & 1.13 & 0.72 \\
\hline $0.173 \mathrm{Q}[7]$ & 7.65 & $\backslash$ & 3.86 & 3.22 & 1.87 & 1.62 & 1.14 & 0.69 \\
\hline $0.331 \mathrm{Q}[7]$ & 7.56 & $\backslash$ & 3.83 & 3.14 & 1.86 & 1.60 & 1.14 & 0.67 \\
\hline $0.474 \mathrm{Q}[7]$ & 7.46 & $\backslash$ & 3.78 & 3.06 & 1.85 & 1.58 & 1.14 & 0.64 \\
\hline $0.641 \mathrm{Q}[7]$ & 7.36 & $\backslash$ & 3.74 & 2.98 & 1.83 & 1.57 & 1.14 & 0.60 \\
\hline $0.750 \mathrm{Q}[7]$ & 7.27 & $\backslash$ & 3.71 & 2.91 & 1.82 & 1.55 & 1.15 & 0.58 \\
\hline $1.164 \mathrm{Q}[7]$ & 7.16 & $\backslash$ & 3.64 & 2.82 & 1.80 & 1.53 & 1.15 & 0.54 \\
\hline $1.653 \mathrm{Q}[7]$ & 7.16 & 5.45 & 3.64 & 2.82 & 1.80 & 1.53 & 1.15 & 0.54 \\
\hline
\end{tabular}


Table A4. Data from the ${ }^{1} \mathrm{H}$ NMR spectra for the interaction of C6 and different proportions of Q[7].

\begin{tabular}{ccccccccc}
\hline & Hd & Hc & He & Hb & Ha & Hf & Hg-i & Hj \\
\hline C6 & 7.79 & 6.56 & 3.93 & 3.33 & 1.90 & 1.67 & 1.12 & 0.68 \\
\hline 0.110 Q[7] & 7.76 & 6.54 & 3.91 & 3.30 & 1.89 & 1.65 & 1.11 & 0.66 \\
\hline 0.223 Q[7] & 7.72 & $\backslash$ & 3.87 & 3.26 & 1.87 & 1.63 & 1.11 & 0.65 \\
\hline 0.363 Q[7] & 7.68 & $\backslash$ & 3.82 & 3.19 & 1.85 & 1.60 & 1.10 & 0.63 \\
\hline $0.461 \mathrm{Q}[7]$ & 7.64 & $\backslash$ & 3.77 & 3.04 & 1.84 & 1.57 & 1.09 & 0.62 \\
\hline 0.646 Q[7] & 7.59 & $\backslash$ & 3.72 & 2.95 & 1.82 & 1.55 & 1.08 & 0.60 \\
\hline 0.739 Q[7] & 7.56 & 5.86 & 3.68 & 2.89 & 1.80 & 1.52 & 1.08 & 0.58 \\
\hline $0.997 \mathrm{Q}[7]$ & 7.52 & 5.81 & 3.64 & 2.84 & 1.78 & 1.49 & 1.07 & 0.56 \\
\hline $1.494 \mathrm{Q}[7]$ & 7.52 & 5.81 & 3.64 & 2.84 & 1.78 & 1.49 & 1.07 & 0.56 \\
\hline
\end{tabular}
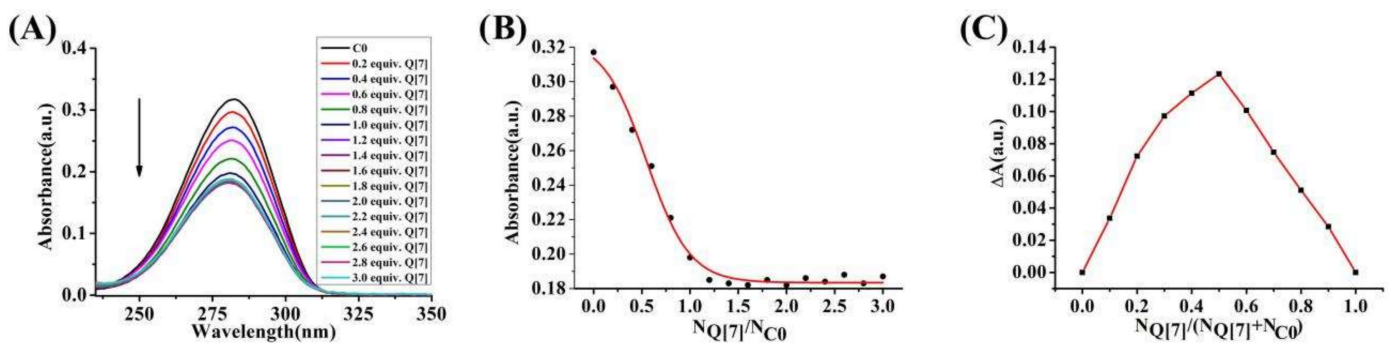

Figure A3. (Color online) (A) Electronic absorption of $\mathrm{C} 0\left(2 \times 10^{-5} \mathrm{~mol} \mathrm{~L}^{-1}\right)$ upon addition of increasing amounts $\left(0,0.2,0.4 \cdots \cdots \cdot 2.6,2.8,3.0\right.$ equiv.) of $\mathrm{Q}[7] ;$ (B) the concentrations and absorbance $v s . \mathrm{N}_{\mathrm{Q}[7]} / \mathrm{N}_{\mathrm{C} 0}$ plots; (C) the corresponding $\Delta \mathrm{A}-\mathrm{N}_{\mathrm{Q}[7]} /\left(\mathrm{N}_{\mathrm{Q}[7]}+\mathrm{N}_{\mathrm{C} 0}\right)$ curves.

(A)

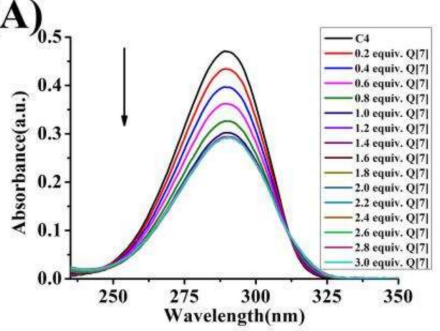

(B)

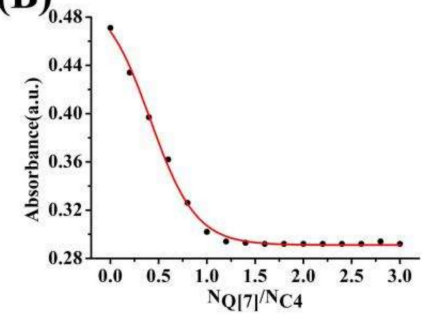

(C)

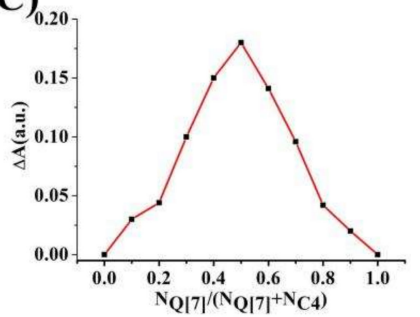

Figure A4. (Color online) (A) Electronic absorption of $\mathrm{C} 4\left(2 \times 10^{-5} \mathrm{~mol} \mathrm{~L}^{-1}\right)$ upon addition of increasing amounts $\left(0,0.2,0.4 \cdots \cdots \cdot 2.6,2.8,3.0\right.$ equiv.) of $\mathrm{Q}[7] ;$ (B) the concentrations and absorbance $v s . \mathrm{N}_{\mathrm{Q}[7]} / \mathrm{N}_{\mathrm{C} 4}$ plots; (C) the corresponding $\Delta \mathrm{A}-\mathrm{N}_{\mathrm{Q}[7]} /\left(\mathrm{N}_{\mathrm{Q}[7]}+\mathrm{N}_{\mathrm{C} 4}\right)$ curves.

(A)

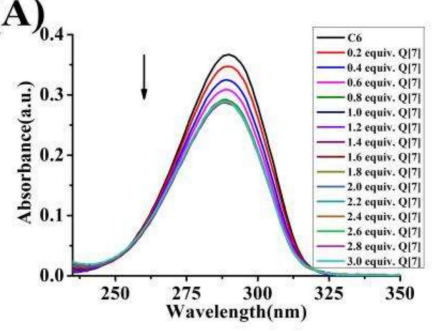

(B)

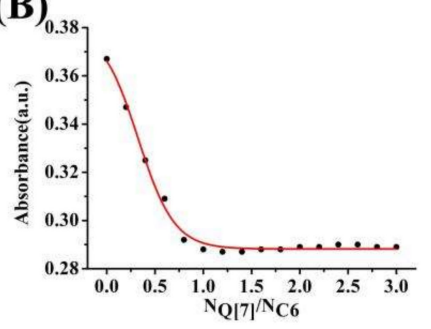

(C)

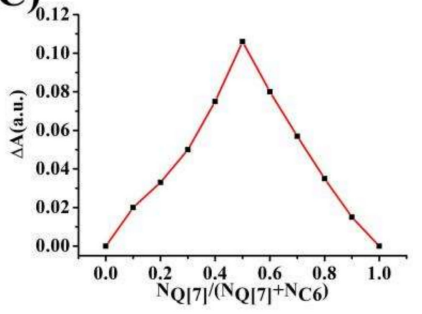

Figure A5. (Color online) (A) Electronic absorption of C6 $\left(2 \times 10^{-5} \mathrm{~mol} \mathrm{~L}^{-1}\right)$ upon addition of increasing amounts $\left(0,0.2,0.4 \cdots \cdots 2.6,2.8,3.0\right.$ equiv.) of $\mathrm{Q}[7] ;(\mathbf{B})$ the concentrations and absorbance $v$ s. $\mathrm{N}_{\mathrm{Q}[7]} / \mathrm{N}_{\mathrm{C} 6}$ plots; (C) the corresponding $\Delta \mathrm{A}-\mathrm{N}_{\mathrm{Q}[7]} /\left(\mathrm{N}_{\mathrm{Q}[7]}+\mathrm{N}_{\mathrm{C} 6}\right)$ curves.

Guests C0, C2, C4, C6 were synthesized by previously reported methods. [23].

Synthesis of guest C0: 4-pyrrolidinopyridine $(296 \mathrm{mg}, 0.002 \mathrm{~mol})$ and $\mathrm{HCl}(10 \mathrm{~mL})$ were stirred under an inert nitrogen atmosphere and heated to $80^{\circ} \mathrm{C}$ and refluxed for $12 \mathrm{~h}$. The resulting solution 
was filtered and then the white precipitate was washed with diethyl ether and dried in vacuum to give $\mathrm{C} 0(331 \mathrm{mg}, 90 \%) .{ }^{1} \mathrm{H}$ NMR $\left(\mathrm{D}_{2} \mathrm{O}, 400 \mathrm{MHz}\right) \delta: 7.79(\mathrm{~d}, \mathrm{~J}=7.5 \mathrm{~Hz}, 2 \mathrm{H}), 6.58(\mathrm{~d}, \mathrm{~J}=7.5 \mathrm{~Hz}, 2 \mathrm{H}), 3.35$ $(\mathrm{t}, \mathrm{J}=6.8 \mathrm{~Hz}, 4 \mathrm{H}), 1.94-1.89(\mathrm{~m}, 4 \mathrm{H}) .{ }^{13} \mathrm{C}$ NMR $(101 \mathrm{MHz}) \delta: 154.65,137.82,107.26,48.09,24.65$. Anal. Calcd. for $\mathrm{C}_{9} \mathrm{H}_{13} \mathrm{~N}_{2} \mathrm{Cl}$ : C, 58.54; $\mathrm{H}, 7.10 ; \mathrm{N}, 15.17$; found $\mathrm{C}, 57.92 ; \mathrm{H}, 7.18 ; \mathrm{N}, 15.93$. The ${ }^{1} \mathrm{H}$ NMR (top) $(400 \mathrm{MHz})$ and ${ }^{13} \mathrm{C}$ NMR (below) $(100 \mathrm{MHz})$ spectra of $\mathrm{C} 0$ in $\mathrm{D}_{2} \mathrm{O}$ are presented in Figure A6.

Synthesis of guest C2: 4-pyrrolidinopyridine $(296 \mathrm{mg}, 0.002 \mathrm{~mol})$ and bromoethane (1.308 $\mathrm{g}$, $0.012 \mathrm{~mol})$ were dissolved in acetonitrile $(40 \mathrm{~mL})$. The solution was stirred under an inert nitrogen atmosphere and heated to $80{ }^{\circ} \mathrm{C}$ and refluxed for $12 \mathrm{~h}$. The resulting solution was filtered and then the yellow precipitate was washed with diethyl ether and then dried in vacuum to give $\mathrm{C} 2(437 \mathrm{mg}$, 85\%). ${ }^{1} \mathrm{H}$ NMR $\left(\mathrm{D}_{2} \mathrm{O}, 400 \mathrm{MHz}\right) \delta: 7.78(\mathrm{~d}, \mathrm{~J}=7.6 \mathrm{~Hz}, 2 \mathrm{H}), 6.54(\mathrm{~d}, \mathrm{~J}=7.5 \mathrm{~Hz}, 2 \mathrm{H}), 3.94(\mathrm{q}, \mathrm{J}=7.3 \mathrm{~Hz}$, $2 \mathrm{H}), 3.30(\mathrm{~m}, \mathrm{~J}=8.0 \mathrm{~Hz}, 4 \mathrm{H}), 1.90-1.84(\mathrm{~m}, 4 \mathrm{H}), 1.25(\mathrm{t}, \mathrm{J}=7.3 \mathrm{~Hz}, 3 \mathrm{H}) .{ }^{13} \mathrm{C}$ NMR $(101 \mathrm{MHz}) \delta 153.50$, 140.95, 108.23, 52.98, 48.15, 24.82, 15.42. Anal. Calcd. for $\mathrm{C}_{11} \mathrm{H}_{17} \mathrm{~N}_{2} \mathrm{Br}: \mathrm{C}, 51.37 ; \mathrm{H}, 6.66 ; \mathrm{N}, 10.89$; found C, 51.29; H, 6.71; N, 10.92. The ${ }^{1} \mathrm{H}$ NMR (top) (400 MHz) and ${ }^{13} \mathrm{C}$ NMR (below) (100 MHz) spectra of $\mathrm{C} 2$ in $\mathrm{D}_{2} \mathrm{O}$ are presented in Figure A7.

Synthesis of guest $\mathrm{C} 4$ : The same method as for $\mathrm{C} 2$ was employed, but using 4-pyrrolidinopyridine (296 mg, $0.002 \mathrm{~mol})$ and bromobutane $(1.644 \mathrm{~g}, 0.012 \mathrm{~mol})$ to give C4 $(496 \mathrm{mg}, 87 \%) .{ }^{1} \mathrm{H} \mathrm{NMR}$ $\left(\mathrm{D}_{2} \mathrm{O}, 400 \mathrm{MHz}\right) \delta: 7.79(\mathrm{~d}, \mathrm{~J}=7.6 \mathrm{~Hz}, 2 \mathrm{H}), 6.57(\mathrm{~d}, \mathrm{~J}=7.5 \mathrm{~Hz}, 2 \mathrm{H}), 3.94(\mathrm{t}, \mathrm{J}=7.1 \mathrm{~Hz}, 2 \mathrm{H}), 3.34(\mathrm{t}, \mathrm{J}=6.7$ $\mathrm{Hz}, 4 \mathrm{H}), 1.93-1.88(\mathrm{~m}, 4 \mathrm{H}), 1.66(\mathrm{~m}, \mathrm{~J}=14.8 \mathrm{~Hz}, 2 \mathrm{H}), 1.14(\mathrm{~m}, \mathrm{~J}=14.8 \mathrm{~Hz}, 2 \mathrm{H}), 0.75(\mathrm{t}, \mathrm{J}=7.4 \mathrm{~Hz}$, 3H). ${ }^{13} \mathrm{C}$ NMR $\left(\mathrm{D}_{2} \mathrm{O}, 101 \mathrm{MHz}\right) \delta$ : 153.52, 141.23, 107.82, 57.46, 48.24, 32.12, 24.78, 18.73, 12.69. Anal. Calcd. for $\mathrm{C}_{13} \mathrm{H}_{21} \mathrm{~N}_{2} \mathrm{Br}$ : C, 54.74; $\mathrm{H}, 7.42 ; \mathrm{N}, 9.82$; found $\mathrm{C}, 54.82 ; \mathrm{H}, 7.47 ; \mathrm{N}, 9.75$. The ${ }^{1} \mathrm{H}$ NMR (top) (400 MHz) and ${ }^{13} \mathrm{C}$ NMR (below) (100 MHz) spectra of $\mathrm{C} 4$ in $\mathrm{D}_{2} \mathrm{O}$ are as presented in Figure A8.

Synthesis of guest $\mathrm{C} 6$ : The same method as for $\mathrm{C} 2$ was employed, but using 4-pyrrolidinopyridine (296 mg, $0.002 \mathrm{~mol})$ and bromohexane $(1.981 \mathrm{~g}, 0.012 \mathrm{~mol})$ to give C6 (551 mg, 88\%). ${ }^{1} \mathrm{H} \mathrm{NMR}$ $\left(\mathrm{D}_{2} \mathrm{O}, 400 \mathrm{MHz}\right) \delta: 7.79(\mathrm{~d}, \mathrm{~J}=7.0 \mathrm{~Hz}, 2 \mathrm{H}), 6.57(\mathrm{~d}, \mathrm{~J}=7.1 \mathrm{~Hz}, 2 \mathrm{H}), 3.94(\mathrm{q}, \mathrm{J}=7.0 \mathrm{~Hz}, 2 \mathrm{H}), 3.35$ $(\mathrm{d}, \mathrm{J}=6.1 \mathrm{~Hz}, 4 \mathrm{H}), 1.91(\mathrm{~m}, 4 \mathrm{H}), 1.68(\mathrm{~m}, \mathrm{~J}=6.6 \mathrm{~Hz}, 2 \mathrm{H}), 1.12(\mathrm{~m}, 6 \mathrm{H}), 0.69(\mathrm{t}, \mathrm{J}=6.4 \mathrm{~Hz}, 3 \mathrm{H}) .{ }^{13} \mathrm{C} \mathrm{NMR}$ (400 MHz) $\delta$ : 153.52, 141.23, 108.22, 57.42, 48.24, 30.42, 29.94, 24.90, 24.77, 21.80, 13.21. Anal. Calcd. for $\mathrm{C}_{15} \mathrm{H}_{25} \mathrm{~N}_{2} \mathrm{Br}$ : C, 57.51; $\mathrm{H}, 8.04 ; \mathrm{N}, 8.94$; found $\mathrm{C}, 57.48 ; \mathrm{H}, 8.11 ; \mathrm{N}, 8.99$. The ${ }^{1} \mathrm{H}$ NMR (top) (400 MHz) and 13C NMR (below) $(100 \mathrm{MHz})$ spectra of $\mathrm{C} 6$ in $\mathrm{D}_{2} \mathrm{O}$ are as presented in Figure A9.
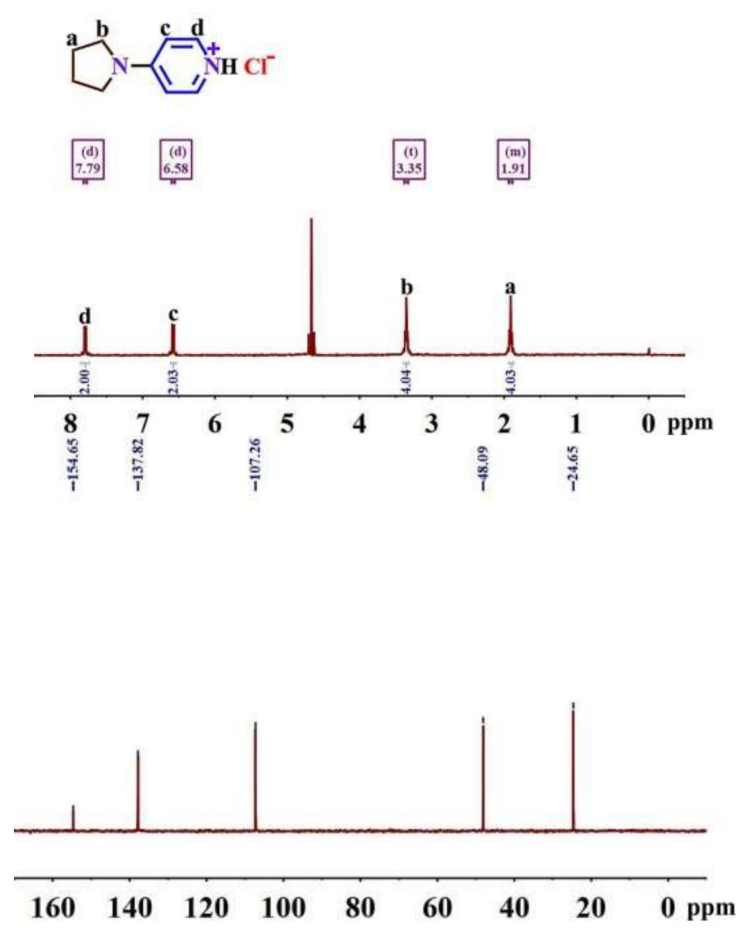

Figure A6. ${ }^{1} \mathrm{H}$ NMR (top) (400 MHz) and ${ }^{13} \mathrm{C}$ NMR (below) $(100 \mathrm{MHz})$ spectra of $\mathrm{C} 0$ in $\mathrm{D}_{2} \mathrm{O}$. 

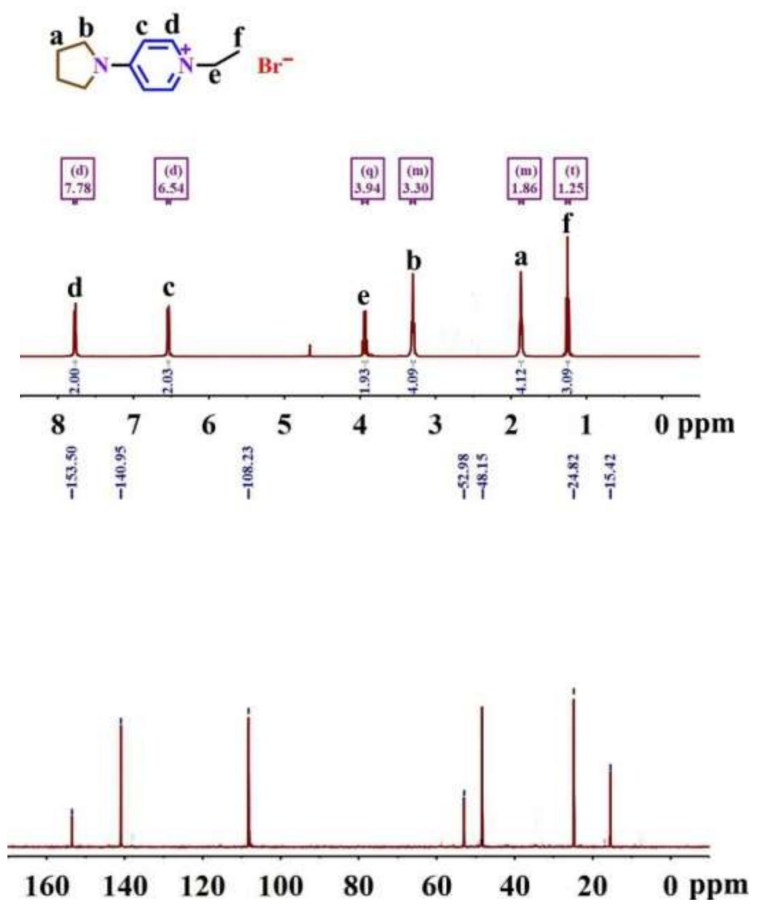

Figure A7. ${ }^{1} \mathrm{H}$ NMR (top) $(400 \mathrm{MHz})$ and ${ }^{13} \mathrm{C}$ NMR (below) $(100 \mathrm{MHz})$ spectra of $\mathrm{C} 2$ in $\mathrm{D}_{2} \mathrm{O}$.<smiles>CC(CBr)C(C)C[Si](C)(C)N1C=CC(N2CCCC2)CC1</smiles>
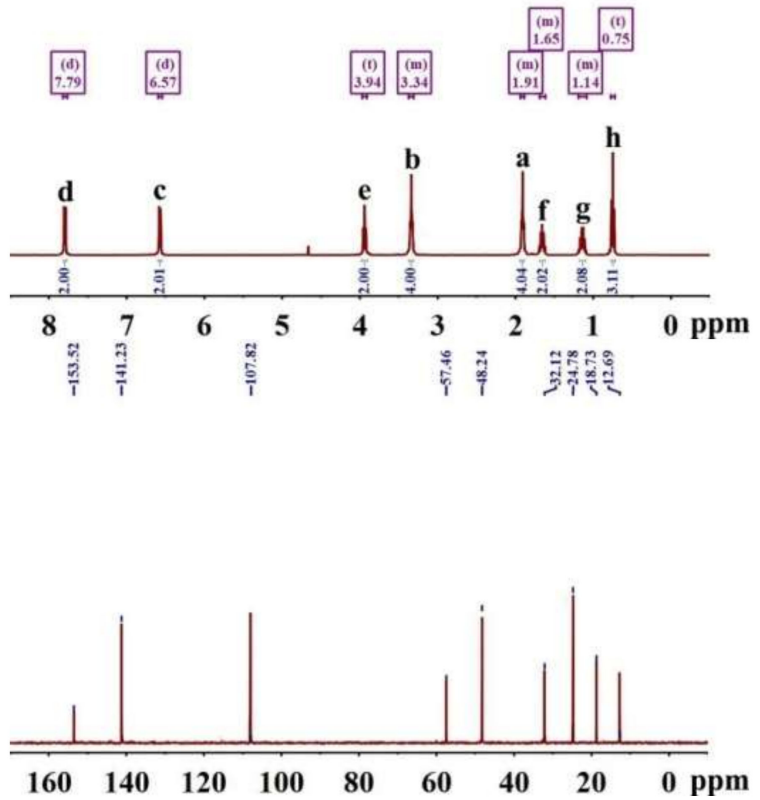

Figure A8. ${ }^{1} \mathrm{H}$ NMR (top) (400 MHz) and ${ }^{13} \mathrm{C}$ NMR (below) (100 MHz) spectra of $\mathrm{C} 4$ in $\mathrm{D}_{2} \mathrm{O}$. 


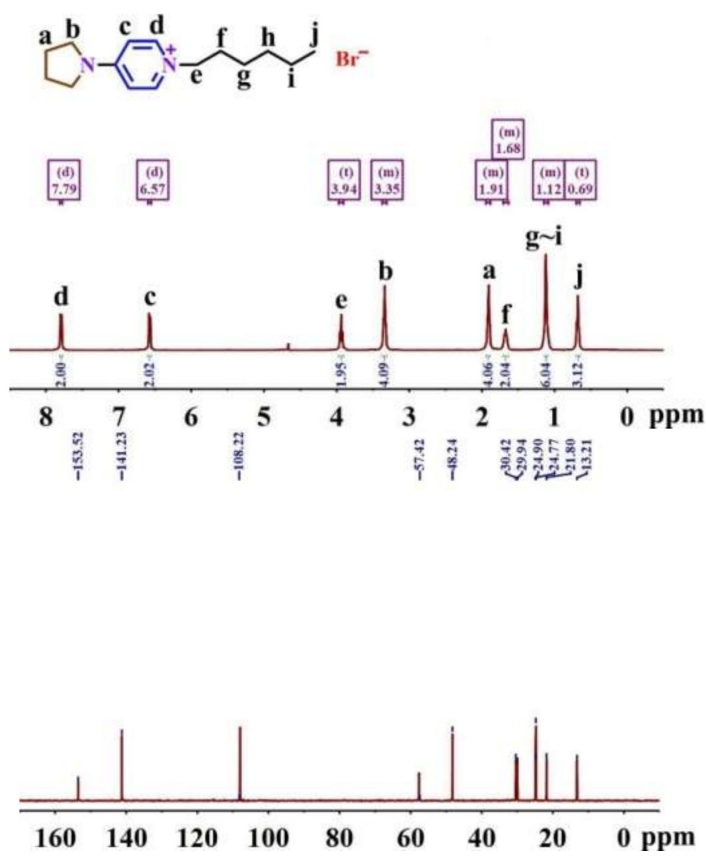

Figure A9. ${ }^{1} \mathrm{H}$ NMR (top) $(400 \mathrm{MHz})$ and ${ }^{13} \mathrm{C}$ NMR (below) $(100 \mathrm{MHz})$ spectra of $\mathrm{C} 6$ in $\mathrm{D}_{2} \mathrm{O}$.

\section{References}

1. Zhang, W.; Luo, Y.; Zhou, Y.; Liu, M.; Xu, W.; Bian, B.; Tao, Z.; Xin, X. A highly selective fluorescent chemosensor probe for the detection of $\mathrm{Fe}^{3+}$ and $\mathrm{Ag}^{+}$based on supramolecular assembly of cucubit[10]uril with a pyrene derivative. Dyes Pigment. 2020, 176, 108235-108242. [CrossRef]

2. Lucenti, E.; Forni, A.; Botta, C.; Carlucci, L.; Giannini, C.; Marinotto, D.; Previtali, A.; Righetto, S.; Cariati, E. $\mathrm{H}$-aggregates granting crystallization-induced emissive behavior and ultralong phosphorescence from a pure organic molecule. J. Phys. Chem. Lett. 2017, 8, 1894-1898. [CrossRef]

3. Bian, L.; Shi, H.; Wang, X.; Ling, K.; Ma, H.; Li, M.; Cheng, Z.; Ma, C.; Cai, S.; Wu, Q.; et al. Simultaneously enhancing efficiency and lifetime of ultralong organic phosphorescence materials by molecular self-assembly. J. Am. Chem. Soc. 2018, 140, 10734-10739. [CrossRef] [PubMed]

4. You, L.; Zha, D.; Anslyn, E.V. Recent advances in supramolecular analytical chemistry using optical sensing. Chem. Rev. 2015, 115, 7840-7892. [CrossRef] [PubMed]

5. Dale, E.J.; Vermeulen, N.A.; Juricek, M.; Barnes, J.C.; Young, R.M.; Wasielewski, M.R.; Stoddart, J.F. Supramolecular Ex plorations: Ex hibiting the Ex tent of Ex tended cationic cyclophanes. Acc. Chem. Res. 2016, 49, 262-273. [CrossRef] [PubMed]

6. Barrow, S.J.; Kasera, S.; Rowland, M.J.; del Barrio, J.; Scherman, O.A. Cucurbituril-based molecular recognition. Chem. Rev. 2015, 115, 12320-12406. [CrossRef]

7. Yu, G.; Jie, K.; Huang, F. Supramolecular amphiphiles based on host-guest molecular recognition motifs. Chem. Rev. 2015, 115, 7240-7303. [CrossRef]

8. Wu, M.X.; Yang, Y.W. Metal-organic framework (MOF)-based drug/cargo delivery and cancer therapy. Adv. Mater. 2017, 29, 1606134. [CrossRef]

9. Diederich, F. Complexation of neutral molecules by cyclophane hosts. Angew. Chem. Int. Ed. Engl. 1988, 27, 362-386. [CrossRef]

10. Xue, M.; Yang, Y.; Chi, X.; Zhang, Z.; Huang, F. Pillararenes, a new class of macrocycles for supramolecular chemistry. Acc. Chem. Res. 2012, 45, 1294-1308. [CrossRef]

11. Rebek, J. Molecular behavior in small spaces. Acc. Chem. Res. 2009, 42, 1660-1668. [CrossRef] [PubMed]

12. Zarra, S.; Wood, D.M.; Roberts, D.A.; Nitschke, J.R. Molecular containers in complex chemical systems. Chem. Soc. Rev. 2015, 44, 419-432. [CrossRef] [PubMed]

13. Szente, L.; Szejtli, J. Highly soluble cyclodextrin derivatives: Chemistry, properties, and trends in development. Adv. Drug Delivery Rev. 1999, 36, 17-28. [CrossRef] 
14. Pedersen, C.J. The discovery of crown ethers (Noble Lecture). Angew. Chem. Int. Ed. Engl. 1988, 27, 1021-1027. [CrossRef]

15. Masson, E.; Ling, X.; Roymon, J.; Kyeremeh-Mensah, L.; Lu, X. Cucurbituril chemistry: A tale of supramolecular success. RSC Adv. 2012, 2, 1213-1247. [CrossRef]

16. Kim, K. Mechanically interlocked molecules incorporating cucurbituril and their supramolecular assemblies. Chem. Soc. Rev. 2002, 31, 96-107. [CrossRef]

17. Assaf, K.I.; Nau, W.M. Cucurbiturils: From synthesis to high-affinity binding and catalysis. Chem. Soc. Rev. 2015, 44, 394-418. [CrossRef]

18. Lagona, J.; Mukhopadhyay, P.; Chakrabarti, S.; Isaacs, L. The cucurbit $[n]$ uril family. Angew. Chem. Int. Ed. 2005, 44, 4844-4870. [CrossRef]

19. Gomez-Casado, A.; Jonkheijm, P.; Huskens, J. Recognition properties of cucurbit[7]uril self-assembled monolayers studied with force spectroscopy. Langmuir 2011, 27, 11508-11513. [CrossRef]

20. Bosmans, R.P.; Briels, J.M.; Milroy, L.G.; de Greef, T.F.; Merkx, M.; Brunsveld, L. Supramolecular Control over Split-Luciferase Complementation. Angew. Chem. Int. Ed. 2016, 55, 8899-8903. [CrossRef]

21. Mock, W.L.; Shih, N.Y. Host-guest binding capacity of cucurbituril. J. Org. Chem. 1983, 48, 3618. [CrossRef]

22. Walker, S.; Oun, R.; McInnes, F.J.; Wheate, N.J. The potential of cucurbit $[n]$ urils in drug delivery. Isr. J. Chem. 2011, 51, 616-624. [CrossRef]

23. Xu, W.; Kan, J.; Yang, B.; Prior, T.J.; Bian, B.; Xiao, X.; Tao, Z.; Redshaw, C. A Study of the Interaction Between Cucurbit[8]uril and Alkyl-Substituted 4-Pyrrolidinopyridinium Salts. Chem. Asian J. 2019, 14, 235-242. [CrossRef]

24. Xu, W.; Liu, M.; Escanõ, M.C.; Redshaw, C.; Bian, B.; Fan, Y.; Tao, Z.; Xiao, X. Alkyl substituted 4-pyrrolidinopyridinium salts encapsulated in the cavity of cucurbit[10]uril. New J. Chem. 2019, 43, 7028-7034. [CrossRef]

25. Ji, L.; Yang, L.; Yu, Z.Y.; Tan, C.S.; Parker, R.M.; Abell, C.; Scherman, O.A. Cucurbit[n] uril-based microcapsules self-assembled within microfluidic droplets: A versatile approach for supramolecular architectures and materials. Accounts Chem. Res. 2017, 50, 208-217.

26. Yamanaka, M.; Yoshida, U.; Sato, M.; Shigeta, T.; Yoshida, K.; Furuta, T.; Kawabata, T.J. Origin of high E-selectivity in 4-pyrrolidinopyridine-catalyzed tetrasubstituted $\alpha, \alpha^{\prime}$-alkenediol: A computational and experimental study. Org. Chem. 2015, 80, 3075-3082. [CrossRef] [PubMed]

27. Sammaki, T.; Hurley, T.B. 2-formyl-4-pyrrolidinopyridine (FPP): A new catalyst for the hydroxyl-directed methanolysis of esters. J. Am. Chem. Soc. 1996, 118, 8967-8968. [CrossRef]

28. Nguyen, H.V.; Butler, D.C.; Richards, C.J. A metallocene-pyrrolidinopyridine nucleophilic catalyst for asymmetric synthesis. Org. Lett. 2006, 8, 769-772. [CrossRef] 